\title{
Retrospective Study of the Restoration of Neuromuscular Blockage with Sugammadex in Newborns Who Used Rocuronium
}

\author{
• Hacer Şebnem Türk, @ Leyla Kılınc, ๑ Pınar Sayın, ๑ Sibel Oba
}

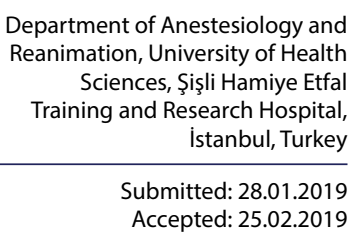

Department of Anestesiology and Reanimation, University of Health Sciences, Şişli Hamiye Etfal Training and Research Hospital, İstanbul, Turkey

Submitted: 28.01.2019 Accepted: 25.02.2019

Correspondence: Hacer Şebnem Türk, SBÜ Şişli Hamidiye Etfal Eğitim ve Araştırma Hastanesi, Anestezioloji ve Reanimasyon Kliniği, İstanbul, Turkey

E-mail: hacersebnem@yahoo.com.tr

\section{(5)

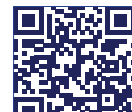 \\ 무룰}

Keywords: Newborn; postoperative residual curarization; sugammadex.

This work is licensed under a Creative Common Attribution-NonCommercial 4.0 International License.

\begin{abstract}
Objective: The aim of the present study was to discuss the effects of antagonism of neuromuscular blockade with sugammadex on extubation success and residual curarization in neonates with retrospective data.
\end{abstract}

\begin{abstract}
Methods: The present study was conducted as a retrospective analysis of the data of 27 neonates aged $\leq 40$ days who underwent abdominal surgery between January 2012 and December 2013. Rocuronium was used for anesthesia induction, and patients whose neuromuscular blockade was antagonized by sugammadex and who were monitored with train-of-four (TOF) were included in the study. The dose of rocuronium administered, the dose of sugammadex, the duration of the operation and anesthesia, elapsed time from the last dose of rocuronium to sugammadex administration and elapsed time from sugammadex administration to extubation, and TOF values during extubation were recorded from the anesthesia records.
\end{abstract}

Results: The mean age of the patients was $10.29 \pm 11.80$ days. The mean weight was $3.04 \pm 1.92 \mathrm{~kg}$. The mean sugammadex dose was $3.6 \mathrm{mg} / \mathrm{kg}$. The elapsed time from the last rocuronium to sugammadex administration was $27.3 \pm 7.7 \mathrm{~min}$, the elapsed time from sugammadex administration to extubation was $1.05 \pm 0.6 \mathrm{~min}$, and the TOF value during extubation was $93.5 \pm 7.3$. The time to reach TOF 0.9 was $88.11 \pm 21.06 \mathrm{~s}$.

Conclusion: Sugammadex, which is used for the reversal of neuromuscular blockade in neonates, showed a similar efficacy as in adult and pediatric patient studies. Safe extubation can be performed in neonates in a short period with sugammadex.

\section{INTRODUCTION}

Rocuronium is the most common neuromuscular blocker (NMB) used in daily anesthesia practice in all age groups, including newborns. NMBs can cause postoperative residual curarization, airway obstruction, and mortal complications, such as aspiration and hypoxia. For this reason, at the end of the operation, the effect of NMB should be rapidly antagonized. Acetylcholinesterase inhibitors have been used for many years to antagonize NMB, but the rate of residual curarization is rather high. ${ }^{[1,2]}$

Sugammadex has been developed to safely reverse neuromuscular blockage created by rocuronium and vecuronium. Studies in adults have shown efficacy and safety of the use of sugammadex in NMB antagonism and its appropriate dose ranges. ${ }^{[3-5]}$ Studies in children over the past years have revealed that sugammadex has similar efficacy in children as in adults. ${ }^{[6-8]}$

The increase in the quality of newborn care increased the survival rate in newborns with anomalies and increased the frequency of operation due to existing anomalies as a result. The use of sugammadex for the NMB antagonism after rocuronium administration for neonatal anesthesia has been suggested. However, there are not enough studies in this area. ${ }^{[9]}$

The aim of the present study was to discuss the reversal of NMB with sugammadex in newborns with retrospective data for clinical extubation success and residual curarization frequency.

\section{MATERIALS AND METHODS}

After ethical approval was obtained (SEEAH/06.03.2018/ 962 ), the study was conducted as a retrospective analysis of the data of 27 newborns who were aged $\leq 40$ days and who underwent abdominal surgery at the pediatric surgery clinic between January 2012 and December 2013. Rocuronium was used for the induction of anesthesia. NMB antagonism was applied with sugammadex and monitored with train-of-four (TOF). 
Patients who were $>40$ days, whose anesthesiology records could not be obtained, and who were not monitored with TOF despite rocuronium and sugammadex administered were excluded from the study.

The anesthesia records of the patients were assessed, and age, sex, and weight and the diagnosis before the operation were recorded. During the operation, apical heartbeat and peripheral oxygen saturation levels of all patients were monitored, and capnograph, anesthetic gas analyzer, and esophageal thermometer were also used for monitorization. Neuromuscular function was monitored with the TOF stimulation of the ulnar nerve (TOF-Watch ${ }^{\mathrm{TM}} \mathrm{SX}$; Schering-Plow Ireland Ltd., Dublin, Ireland). Mask induction with $8 \%$ sevoflurane, intravenous I $\mu \mathrm{g} / \mathrm{kg}$ fentanyl, and rocuronium at a dose of $0.7-0.9 \mathrm{mg} / \mathrm{kg}$ were used in anesthesia induction. Intubation was performed with 2.5-3.0 intubation tube without cuff. At the end of the operation, NMB antagonization was performed with $2-4 \mathrm{mg} / \mathrm{kg}$ sugammadex. All of the patients were extubated based on clinical observation.

The dose of rocuronium applied, the dose of sugammadex, the duration of the operation and anesthesia, time elapsed from the latest dose of rocuronium to sugammadex application and from sugammadex to extubation, and TOF values during extubation were recorded from the anesthesia records of the patients.

The duration of the operation was defined as the time from skin incision to the last suture. The duration of anesthesia was defined as the time from the induction of anesthesia to when the patients were fully recovered.

Complications, such as bradycardia, tachycardia, vomiting, desaturation, bronchospasm, apnea, during and after the operation were recorded.

\section{Statistical analysis}

SPSS 15.0 for Windows program (SPSS Inc., Chicago, IL, USA) was used for statistical analysis. For descriptive statistics, numbers were used for categorical variables, and mean and standard deviation were used for numerical variables.

\section{RESULTS}

A total of 313 newborns underwent abdominal surgery between January 2012 and December 2013. Twenty-seven newborns were given rocuronium for anesthesia induction. NMB antagonization was performed with sugammadex and was monitored with TOF.

The diagnostic distribution of the patients is shown in Table I. The average age of the patients was $10.2 \pm 11.8$ days. The male-to-female ratio was $11 / 16$, and the average weight was $3 \pm 1.9 \mathrm{~kg}$. The duration of the operation was $60.5 \pm 29.8 \mathrm{~min}$, and the duration of anesthesia was $63.7 \pm 25.8 \mathrm{~min}$ (Table 2). Rocuronium dose was $2.8 \pm 1.5$ $\mathrm{mg}$, and sugammadex dose was $11.2 \pm 5.4 \mathrm{mg}$. The mean sugammadex dose was $3.6 \mathrm{mg} / \mathrm{kg}$. The time from the last
Table I. Diagnostic distribution of the patients

\begin{tabular}{lc}
\hline & $\mathbf{n = 2 7}$ \\
\hline Inguinal hernia & 9 \\
Necrotizing enterocolitis & 5 \\
Pylorostenosis & 4 \\
Anorectal malformation & 4 \\
lleal atresia & 2 \\
Duodenal atresia & 1 \\
lleus & 2 \\
\hline
\end{tabular}

Table 2. Demographical data and time intervals

\begin{tabular}{lc}
\hline & $\mathbf{n = 2 7}$ (Mean \pm SD) \\
\hline Age (day) & $10.2 \pm 11.8$ \\
Male-to-female ratio & $11 / 16$ \\
Weight $(\mathrm{kg})$ & $3 \pm 1.9$ \\
Operation duration $(\mathrm{min})$ & $60.5 \pm 29.8$ \\
Anesthesia duration $(\mathrm{min})$ & $63.7 \pm 25.8$ \\
\hline SD: Standard deviation. &
\end{tabular}

Table 3. Drug doses, time intervals, and TOF values

\begin{tabular}{lc}
\hline & $\mathbf{n = 2 7}$ (Mean \pm SD) \\
\hline Rocuronium dose $(\mathrm{mg})$ & $2.8 \pm 1.5$ \\
Sugammadex dose $(\mathrm{mg})$ & $11.2 \pm 5.4$ \\
The time from the last application of & $27.3 \pm 7.7$ \\
rocuronium to the administration & \\
of sugammadex (min) & $\mathrm{I} \pm 0.6$ \\
The time from the administration & \\
of sugammadex to extubation $(\mathrm{min})$ & $93.5 \pm 7.3$ \\
TOF value during extubation $(\%)$ & $88.1 \pm 21$ \\
The time to reach TOF $0.9(\mathrm{~s})$ & \\
\hline TOF: Train-of-four; SD: Standard deviation. &
\end{tabular}

application of rocuronium to the administration of sugammadex was $27.3 \pm 7.7 \mathrm{~min}$, the time from the administration of sugammadex to extubation was $I \pm 0.6 \mathrm{~min}$, and the TOF value during extubation was $93.5 \pm 7.3$ (Table 3 ). The time to reach TOF 0.9 was $88.1 \pm 21 \mathrm{~s}$. The TOF value of all patients during extubation was $>0.9$.

None of the patients had complications during the procedure, during the operation, or after the operation.

\section{DISCUSSION}

Neostigmine is most commonly used NMB antagonist. However, it has side effects related to the muscarinic system, such as bradycardia, QT prolongation, bronchospasm, and hypersalivation. ${ }^{[10]}$ In addition, despite NMB antagonism, nicotinic receptors may remain blocked in $60 \%-70 \%$ of the cases postoperatively. This condition is defined as 
postoperative residual curarization. Postoperative residual curarization can cause mortal situations, such as delayed recovery, hypoxia, and metabolic disruptions. ${ }^{[1,2]}$ Sugammadex, which is widely used for NMB antagonism in adult patients in recent years, is an agent that is rocuronium and vecuronium selective, does not have muscarinic side effects, and provides faster and safer recovery than neostigmine. ${ }^{[10]}$

The effectiveness of NMBs in adults and children is different. The extracellular space is larger in children, especially in newborns, than in adults. In newborns, the amount of rocuronium needed to provide sufficient NMB is considerably higher than the previously known doses. In addition, the neuromuscular junction has not developed sufficiently. The ion channels remain open for longer, and the muscles are easily depolarized. In addition, the affinity of receptors for nondepolarizing agents is lower, and the diaphragm is more sensitive to NMB. All of these factors increase the risk of postoperative apnea in newborns. Therefore, NMB antagonism becomes more important. ${ }^{[1,12]}$ The use of sugammadex, which has a low side effect profile and is thought to provide rapid and effective antagonism, has been considered for newborns.

The only monitorization that is recommended for the detection of postoperative residual curarization is acceleromyography. A TOF ratio $>0.9$ is an adequate parameter for muscle function and respiratory safety. ${ }^{[13]}$

There are prospective controlled studies on the use of sugammadex in adult and pediatric patients, but there is no adequate clinical study on its neonatal use, and data are limited to a few case reports. Studies on the pediatric age group have found that the safe extubation duration and sugammadex doses are similar to adults. In addition, when compared with neostigmine and placebo, the time to reach TOF 0.9 is shorter when sugammadex is used, and the incidence of adverse events is lower. ${ }^{[6-8]}$

In the adult studies conducted, doses of $\geq 2 \mathrm{mg} / \mathrm{kg}$ were found to be effective when different doses of sugammadex were compared with respect to the time to reach TOF $0.9 .^{[5]}$

Plaud et al. ${ }^{[12]}$ compared the time to reach TOF 0.9 and plasma concentrations of sugammadex given at 1,2 , and $4 \mathrm{mg} / \mathrm{kg}$ doses after rocuronium is applied in infants (28 days-23 years), in children (2-1I years), and in adolescents ( $12-17$ years), and at $0.5 \mathrm{mg} / \mathrm{kg}$ dose in adults. The duration to reach TOF 0.9 in all age groups with doses of $\geq 2 \mathrm{mg} / \mathrm{kg}$ is significantly shorter in sugammadex than in placebo, and the plasma concentrations are similar. As a result of these studies, the effective sugammadex dose can be accepted as doses of $\geq 2 \mathrm{mg} / \mathrm{kg}$ for children. In our study, the mean sugammadex dose applied was $3.6 \mathrm{mg} / \mathrm{kg}$. The dose of sugammadex administered in our study was $2-4 \mathrm{mg} / \mathrm{kg}$.

Alonso et al., ${ }^{[9]}$ in their study of 23 newborns of whom 8 were I day old and I5 were I-7 days old, applied antagonization with sugammadex at a dose of $4 \mathrm{mg} / \mathrm{kg}$ and found that the times to reach above TOF 0.9 are $1.4 \mathrm{~min}$ for I-day-old patients and I.2 min for I-7-day-old patients. In our study, this duration was $88.1 \pm 2 \mathrm{I}$ s. The average age of the patients was $10.2 \pm 11.8$ days.

In a case report, for the antagonism of rocuronium-induced NMB at $0.9 \mathrm{mg} / \mathrm{kg}$ dose, sugammadex at a dose of $4 \mathrm{mg} / \mathrm{kg}$ was administered to a newborn who was 3 days old, who weighed $2.98 \mathrm{~kg}$, and who was operated for a giant ovarian cyst; TOF reached 0.9 at $90 \mathrm{~s}$; and extubation took place at $8 \mathrm{~min} \cdot{ }^{[14]} \mathrm{In}$ another case report, $12 \mathrm{mg}$ sugammadex was given to a 20 -day-old newborn weighing $2.8 \mathrm{~kg}$, and the time to reach TOF 0.9 was 2 min. ${ }^{[15]} \mathrm{It}$ has been shown that sugammadex, which acts by binding rocuronium directly, can be used safely in the laparoscopic pyloric stenosis operation of a 3-week-old newborn with neonatal myasthenia gravis. ${ }^{[16]}$ In a 2-day-old newborn with prolonged central and peripheral neuromuscular blockage due to rocuronium infusion following tracheal esophageal fistula repair, the central nervous system effects were successfully reversed with sugammadex. ${ }^{[17]}$

The limitations of our study are the evaluation of retrospective data and the lack of a comparison group. There is a need for prospective, randomized, controlled studies to be conducted on this subject.

In conclusion, sugammadex reduced the risk of postoperative residual curarization by shortening the duration of extubation and time required to reach TOF 0.9 in adults and children at similar doses regarding the recovery from neuromuscular blockage in newborns due to rocuronium use. Sugammadex is effective and safe for restoration from neuromuscular blockage caused by the use of rocuronium in the newborn group.

\section{Funding}

Financial support was provided by departmental sources. Ethics Committee Approval

Approved by the Sisli Hamidiye Etfal Training and Research Hospital Ethics committee (date: 06.03.2018, no: 962).

Peer-review

Internally peer-reviewed.

Authorship Contributions

Concept: H.Ş.T., L. K., P.S., S.O.; Design: H.Ş.T., L. K., P.S., S.O.; Data collection \&/or processing: H.Ş.T., L. K., P.S., S.O.; Analysis and/or interpretation: H.Ş.T., L. K., P.S., S.O.; Literature search: H.Ş.T., L. K., P.S., S.O.; Writing: H.Ş.T., L. K., P.S., S.O.; Critical review: H.Ş.T., L. K., P.S., S.O.

Conflict of Interest

None declared.

\section{REFERENCES}

1. Naguib M, Kopman AF, Ensor JE. Neuromuscular monitoring and postoperative residual curarisation: a meta-analysis. $\mathrm{Br} \mathrm{J}$ Anaesth 2007;98:302-16. [CrossRef]

2. Murphy GS, Szokol JW, Marymont JH, Greenberg SB, Avram MJ, Vender JS. Residual neuromuscular blockade and critical respiratory 
events in the postanesthesia care unit. Anesth Analg 2008;107:130-7.

3. Abrishami A, Ho J, Wong J, Yin L, Chung F. Cochrane corner: sugammadex, a selective reversal medication for preventing postoperative residual neuromuscular blockade. Anesth Analg 2010;110:1239. [CrossRef]

4. Plaud B. Sugammadex: something new to improve patient safety or simply a gadget? Ann Fr Anesth Reanim 2009;28 Suppl 2:64-9.

5. Sorgenfrei IF, Norrild K, Larsen PB, Stensballe J, Ostergaard D, Prins $\mathrm{ME}$, et al. Reversal of rocuronium-induced neuromuscular block by the selective relaxant binding agent sugammadex: a dose-finding and safety study. Anesthesiology 2006;104:667-74. [CrossRef]

6. Ghoneim AA, El Beltagy MA. Comparative study between sugammadex and neostigmine in neurosurgical anesthesia in pediatric patients. Saudi J Anaesth 2015;9:247-52. [CrossRef]

7. Kara T, Ozbagriacik O, Turk HS, Isil CT, Gokuc O, Unsal O, et al. Sugammadex versus neostigmine in pediatric patients: a prospective randomized study. [Article in Portuguese] Rev Bras Anestesiol 2014;64:400-5. [CrossRef]

8. Ozgün C, Cakan T, Baltacı B, Başar H. Comparison of reversal and adverse effects of sugammadex and combination of - Anticholinergic-Anticholinesterase agents in pediatric patients. J Res Med Sci 2014;19:762-8.

9. Alonso A, de Boer H D, Booij L. Reversal of rocuronium-induced neuromuscular block by sugammadex in neonates. Eur J Anaesthesiol
2014;31:163. [CrossRef]

10. Srivastava A, Hunter JM. Reversal of neuromuscular block. Br J Anaesth 2009;103:115-29. [CrossRef]

11. Meretoja OA. Neuromuscular block and current treatment strategies for its reversal in children. Paediatr Anaesth 2010;20:591-604. [CrossRef]

12. Plaud B, Meretoja O, Hofmockel R, Raft J, Stoddart PA, van Kuijk $\mathrm{JH}$, et al. Reversal of rocuronium-induced neuromuscular blockade with sugammadex in pediatric and adult surgical patients. Anesthesiology 2009;110:284-94. [CrossRef]

13. Padjama D, Mantha S. Monitoring of neuromuscular junction. Indian J Anaest 2002;46:179-288.

14. Carlos RV, Torres ML, de Boer HD. Rocuronium and sugammadex in a 3 days old neonate for draining an ovarian cyst. Neuromuscular management and review of the literature. Braz J Anesthesiol 2016;66:430-2. [CrossRef]

15. Cardenas VHG, Gonzales FDM. Sugammadex in the neonatal patient. Rev Colomb Anestesiol 2013;41:171-4. [CrossRef]

16. Rubin JE, Ramamurthi RJ. The Role of Sugammadex in Symptomatic Transient Neonatal Myasthenia Gravis: A Case Report. A A Case Rep 2017;9:271-3. [CrossRef]

17. Langley RJ, McFadzean J, McCormack J. The presumed central nervous system effects of rocuronium in a neonate and its reversal with sugammadex. Paediatr Anaesth 2016;26:109-11. [CrossRef]

\section{Rokuronyum Kullanılan Yenidoğanlarda Sugammadeks İle Nöromusküler Blokajın Geri Döndürülmesi: Retrospektif Çalışma}

Amaç: Bu çalışmada amacımız, yenidoğanlarda nöromusküler blokajın sugammadeks ile antagonize edilmesinin, klinik ekstübasyon başarısı ve rezidüel kürarizasyon sıklığı üzerine etkilerini geriye dönük verilerle tartışmaktır.

Gereç ve Yöntem: Bu çalışma 40 gün veya daha küçük yaşta olan ve Ocak 2012 ile Aralık 2013 tarihleri arasında karın ameliyatı geçirmiş 27 yenidoğanın verilerinin geriye dönük analizi olarak yapıldı. Anestezi indüksiyonu için roküronyum kullanılıp, sugammadeks ile antagonize edilen, Train-of-four (TOF) ile izlenen hastalar dahil edildi. Uygulanan roküronyum dozu, sugammadeks dozu, operasyon ve anestezi süresi, en son roküronyum dozundan sugammadeks uygulamasına geçen süre ve sugammadeks uygulamasınadn ekstübasyona kadar geçen süre ve ekstübasyon sırasında TOF değerleri anestezi kayıtlarından alındı.

Bulgular: Ortalama yaş $10.29 \pm$ I I 80 gündü. Ortalama ağılık $3.04 \pm 1.92 \mathrm{~kg}$ idi. Ortalama sugammadeks dozu $3.6 \mathrm{mg} / \mathrm{kg}$ idi. Son roküronyum uygulamasından sugammadeks uygulamasına kadar geçen süre $27.3 \pm 7.7$ dakika, sugammadeks uygulamasından ekstübasyona kadar geçen süre $1.05 \pm 0.6$ dakika idi ve ekstübasyon sırasında TOF değeri $93.5 \pm 7.3$ idi. TOF 0.9 'a ulaşma süresi 88.1 I \pm 21.06 saniyeydi.

Sonuç: Yenidoğanlarda nöromusküler blokajın geri döndürülmesi amacıyla kullanılan sugammadeksin, erişkin ve pediatrik hasta çalışmalarındaki ile benzer etkinlikte olduğu görülmüştür. Yenidoğanlarda sugammadeks ile kısa sürede ve güvenli ekstübasyon gerçekleştirilebilir.

Anahtar Sözcükler: Ameliyat sonrası rezidüel kürarizasyon; sugammadeks, yenidoğan. 